\title{
The effect of ethanol extract of fruit peel jengkol (Archidendron pauciflorum) to spleen histological structure of streptozotocin-induced diabetic rats (Rattus norvegicus)
}

\author{
DESAK MADE MALINI", SELMA ALAMANDA ABADI"v, MADIHAH, WAWAN HERMAWAN \\ Department of Biology, Faculty of Mathematics and Natural Sciences, Universitas Padjadjaran. Jl. Raya Bandung Sumedang KM.21 45363, Jatinangor, \\ West Java, Indonesia. Tel.+62-228-4288828, "email: desak.made@unpad.co.id, "valamandaselma@gmail.com
}

Manuscript received: 18 February 2019. Revision accepted: 26 August 2019.

\begin{abstract}
Malini DM, Abadi SA, Madihah, Hermawan W. 2019. The effect of ethanol extract of fruit peel jengkol (Archidendron pauciflorum) to spleen histological structure of streptozotocin-induced diabetic rats (Rattus norvegicus). Nusantara Bioscience 11: 157161. Diabetes Mellitus (DM) is a chronic endocrine disorder associated with several secondary complications. The spleen is a lymph organ with the main function of filtering red blood cells, immune response and playing any kind of role in diabetes. Despite the currently available anti-diabetic drugs, there are need remedies for alternatives which are economical and safe. One alternative medicine well known by local Indonesian communities to treat DM is the fruit peel of Archidendron pauciflorum. This study aimed to evaluate the histological changes in the spleen following administration of ethanol extract of fruit peel Archidendron Pauciflorum (EEJFP) in the streptozotocin (STZ) - induced diabetic rats. Diabetic rats were used in this study consisting of six groups of four animals each. The treatments given are NC (CMC solution 0.5\%), Positive Control (CMC solution 0.5\%), G (glibenclamide), Treatment 1, 2, and 3 (EEJFP dose 385; 770; $1540 \mathrm{mg} / \mathrm{kg}$ bw). All of the treatment was administered orally to the experimental rats 14 days following induction. The spleen was collected and the histological study was performed using hematoxylin and eosin (H\&E). The parameters observed were the number of necrosis and cell damage score, including fat degeneration, hydropic degeneration, and inflammatory cell. The result showed that EEJFP at dose $385 \mathrm{mg} / \mathrm{kg}$ bw and $770 \mathrm{mg} / \mathrm{kg}$ bw gave significant recovery $(\mathrm{p}<0.05)$ on spleen damage by the decreased of the number of necrotic cells and cell damage score which lower than other treatments and compared to negative control group. It was concluded that doses of $385 \mathrm{mg} / \mathrm{kg}$ bw EEJFP are the optimum dose to improve the histological structure of spleen damage in diabetic rats.
\end{abstract}

Key words: Archidendron pauciflorum, diabetes mellitus, rat, spleen, streptozotocin

\section{INTRODUCTION}

Diabetes Mellitus (DM) is a metabolic disease characterized by hyperglycemia due to insufficient amounts and function of insulin in the abnormality of metabolism, fat, and protein (Soegondo et al. 2011). Diabetes Mellitus is one of the non-communicable diseases in Indonesia that needs attention, because incidence and prevalence are increasing and can be fatal (Cockram 2000; Wild et al 2004; Li 2009). Various acute and negative complications can affect DM patients due to oxidative stress caused by conditions of hyperglycemia (Arnita 2005).

The spleen is a lymphoid organ in the body that has a function of blood filtration and immune response conditioning. The spleen consists of 2 parts. The white part (pulp alba) is the immune system to fight infection and the red part (pulp rubra) removes unnecessary materials from the blood as it breaks (Guyton and Hall 2010). The marginal zone is an area located between the pulp alba, PALS and the follicles. The marginal zone acts as an antigen and pathogen filter in the circulatory system and plays an important role in fighting antigen (Cooper et al. 2002; Mebius and Kraal 2005). Spleen represents a large lymphatic tissue passed by re-circulating lymphocytes, which are able to promptly elicit specific $\mathrm{T}$ or $\mathrm{B}$ lymphocyte mediated immune reactions. This study was designed to assess the effect of WP on the spleen tissues following diabetes (Ebaid et al. 2015).

Streptozotocin (STZ) is a very wide chemical compound that produces the hormone insulin because it can destroy its cells. The induction of STZ as a diabetic agent is very convenient and easy (Abeeleh et al. 2009). The chemical drug experienced by diabetes mellitus is a type of glibenclamide. Adverse effects caused by drugs used for DM purposes are the main reasons for the search for natural antihyperglycemic drugs. Traditional medicine to overcome chronic diseases such as diabetes mellitus (Pramono 2002).

Our previous study showed that local people in Karangwangi village, Cianjur District, West Java used the water decoction of dried jengkol (Archidendron pauciflorum) fruit peels to decrease blood sugar levels (Malini et al. 2017). One of the most commonly available plants in some areas of Indonesia as a drug of diabetes mellitus is jengkol skin. The content of chemical compounds in jengkol skin is alkaloids, steroids/triterpenoids, saponins, flavonoids, and tannins (Syafnir et al. 2014). Therefore, the skin of jengkol fruit ( $A$. pauciflorum) could have the potential to repair the damage to diabetes mellitus. In this research will be discussed the 
effect of ethanol extract of jengkol skin on histology of spleen organ in mouse (Rattus norvegicus) induced by streptozotocin.

\section{MATERIALS AND METHODS}

\section{Procedures}

Preparation of ethanol extract of jengkol fruit peel (EEJFP) was done by maceration method using ethanol $70 \%$. The obtained maserate is then filtered and then concentrated with a rotary evaporator at a temperature of $40^{\circ} \mathrm{C}$ (Khan et al. 2012) to obtain the extract in the paste form. The test animal was acclimatized in animal cage Biology Program for seven days with temperature $22-30^{\circ} \mathrm{C}$. Test animals were given feed and tap water by ad-libitum (Institutional Animal Care and Use Committee of UCONN 2015). Replacement of the chamber cage is done twice a week. The test animal to be used is checked for glucose and fasted for 12 hours.

The test animals were then induced with streptozotocin which was dissolved in $0.1 \mathrm{M}$ citrate buffer ( $\mathrm{pH}$ 4.5) with a single dose of $65 \mathrm{mg} / \mathrm{kg}$ bw intravenously. After 72 hours of STZ induction, blood glucose levels of test animals were examined. Mice that can be used as test animals are mice that have blood glucose $>250 \mathrm{mg} / \mathrm{dl}$ on day 3 (72 hours after STZ induction) (Furman 2015). Fruit ethanol extract of jengkol fruit given orally every day for 14 days in a row according to dose of each treatment. The extract was administered on the $4^{\text {th }}$ day after STZ injection and was considered to be the $1^{\text {st }}$ day and continued for up to 14 days (Sajedianfard 2014).

The experiment used completely randomized design with six treatments and four replications. The rats were randomly divided into 6 groups the animal was divided into 6 groups i.e. Positive Control (PC) (STZ + CMC solution $0.5 \%$ ), Negative Control (NC) (Non-STZ + CMC solution 0.5\%), T1 (STZ + EEJFP dose $385 \mathrm{mg} / \mathrm{kg} \mathrm{bw}), \mathrm{T} 2$ (STZ + EEJFP dose $770 \mathrm{mg} / \mathrm{kg}$ bw), T3 (STZ + EEJFP dose 1540 $\mathrm{mg} / \mathrm{kg}$ bw) and Reference (G) (STZ + Glibenclamide).

After administration of the extract for 14 days, the rat has dislocated the neck, dissected, and isolated the spleen organ. The organs were washed with $0.9 \% \mathrm{NaCl}$ to remove blood residue and dried with filter paper. The histologic preparations of the spleen organ are made by isolated spleen organs fixed in Bouin solution for 24 hours. Then the spleen organ is cut transversely and done washing in alcohol $70 \%$ for 24 hours. Thereafter, the organs are dehydrated in series alcohol and 100\% alcohol-based clarification: xylol. The spleen organ is then infiltrated in xylol: paraffin and embedding in paraffin by oven at 60 $70^{\circ} \mathrm{C}$. Then the organ is cut by using microtom with a thickness of 5 microns at a temperature $<24^{\circ} \mathrm{C}$.

Staining is done by using Hematoxylin-Eosin (HE). The stages performed in this staining begin with unparrafination and then rehydration process in series of alcohol and put into Hematoxilin solution for 25 minutes and the preparation was washed with tap water flowing. Thereafter, the preparation was introduced into a solution of Eosin for $10 \mathrm{~s}$ and dehydrated in a series of alcohols. It is then purified in a solution of xylol series and dried at room temperature and covered with a sliding glass cover.

Histological incision of spleen dyed in HematoxylinEosin was then observed histological structure using a light microscope. The observation of necrosis was performed by looking at 1000 spleen cells, which was then be counted. Other changes were observed, such as infiltration of inflammatory cells, fat degeneration, and hydropic degeneration were scored degrees of its severity using the method Karthikeyan et al. (2007), as follows: (0) no change; (1) mild (focal damage to myocytes or small multifocal degeneration with slight inflammatory processes); (2) moderate (broad myofibrillar degeneration and/or inflammatory of the difusa); (3) severe (widespread degeneration with inflammation of the difusa).

\section{Data analysis}

The histologic observation of rat's spleen (Rattus novergicus) Wistar was analyzed by One-Way ANOVA parametric statistic and continued with Tukey test with 95\% confidence level using SPSS for Windows version 21. In One-Way ANOVA $\mathrm{H}_{0}$ is accepted when $\mathrm{F}_{\text {count }}<\mathrm{F}_{\text {table }}$; and $\mathrm{H}_{1}$ is accepted when $\mathrm{F}_{\text {count }}>\mathrm{F}_{\text {table }}$ at the real level $(\alpha=$ $0,05)$. If $\mathrm{H}_{1}$ is accepted, then the statistical test is continued with the Tukey test.

\section{RESULTS AND DISCUSSION}

Observations of spleen histological structures include the total of necrotic cell, fat degeneration illustrations, hydropic degeneration, and inflammatory cell infiltration. Histological cross-section of the spleen organ of the posttreatment 14-day is presented in Figure 1, with the positive control induced by streptozotocin showed necrotic cells, hydropic degeneration, and inflammatory cell infiltration, whereas on the negative control without the induction of streptozotocin only necrotic cells and hydropic degeneration. Fat degeneration was observed in the treatment of $\mathrm{T} 1$ and $\mathrm{T} 3$.

Based on statistic analyses, the result showed that all treatments of EEJFP give significant effect against the structure of spleen histology compared to control (Table 1). Histopathological studies, section of liver of G treatment (Glibenclamide) and extract animals showed a reduced number of necrotic cells. nclamide) and extract animals showed a reduced number of necrotic cells. Glibenclamide is modern medicine to lower blood glucose levels by stimulating the secretion of insulin (Ratimanjari 2011) as known Insulin serves to regulate blood glucose levels. Table 1 shows that the test animals NC group had a significant difference in the number of cell necrosis ( $p$ $<0.05$ ) than among PC while the PC has a necrotic cell count greater than the other test group. This is due to the induction of STZ in the PC group that can cause tissue damage to the animal's liver test. Induction of streptozotocin better used for the diabetic animal model because they are able to maintain hyperglycemia for a long time (Szkudelski 2001). 

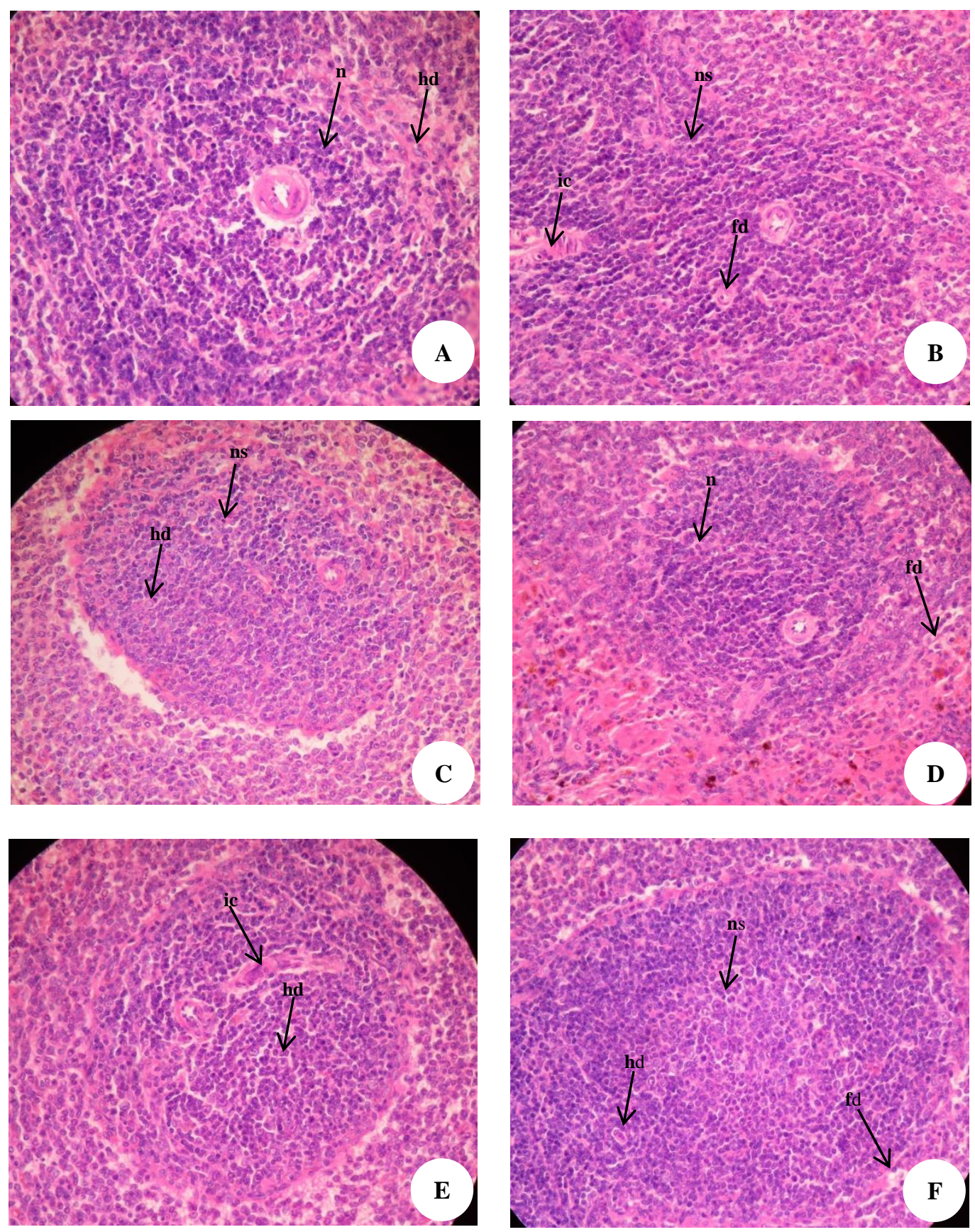

Figure 1. Histological cross section incision of rat's spleen. Note: A. NC; B. PC (STZ $65 \mathrm{mg} / \mathrm{kg} \mathrm{bw}) ;$ C. G (STZ $65 \mathrm{mg} / \mathrm{kg}$ bw + Glibenclamide $10 \mathrm{mg} / \mathrm{kg} \mathrm{bw}$ ); D. T1 (STZ $65 \mathrm{mg} / \mathrm{kg}$ bw + EEJFP $385 \mathrm{mg} / \mathrm{kg} \mathrm{bw);} \mathrm{E.} \mathrm{T2} \mathrm{(STZ} 65 \mathrm{mg} / \mathrm{kg} \mathrm{bw} \mathrm{+} \mathrm{EEJFP} 770 \mathrm{mg} / \mathrm{kg} \mathrm{bw);} \mathrm{F.}$ T3 (STZ $65 \mathrm{mg} / \mathrm{kg}$ bw + EEJFP $1540 \mathrm{mg} / \mathrm{kg} \mathrm{bw}$ ). [n] normal cell; [nc] necrosis cell; [fd] fat degradation; [hd] hydrophic degradation; dan [i] inflammatory cell inflammation

The result of ANAVA test for necrotic cell count shows that $F_{\text {count }}(218,48)>F_{\text {table }}(2,77)$ and ANAVA test for cell damage score showed that $F_{\text {count }}(17,28)>F_{\text {table }}(2,77)$, which means there is a significant difference at least one treatment group showing jengkol fruit peel extract have an effect on histological structure of female wistar rat $(R$. novergicus) spleen organ. The data analysis was continued with Tukey test to find out the most significant different treatment.
Tukey test results showed that rat treated with jengkol fruit peel extract at each dose were significantly different from those given streptozotocin. This means that the administration of jengkol fruit peel extract is able to repair cell damage in the spleen of diabetics by reducing the number of necrosis cells and damage scoring included fat degeneration, hydropic degeneration, and inflammatory cell. In rat that treated with jengkol fruit peel extract at dose of $385 \mathrm{mg} / \mathrm{kg}$ bw and $770 \mathrm{mg} / \mathrm{kg}$ bw did not differ significantly to the control group rats without 
streptozotocin-induced induction. This means that the extract of jengkol fruit peel at dose of $385 \mathrm{mg} / \mathrm{kg}$ bw and $770 \mathrm{mg} / \mathrm{kg} \mathrm{BW}$ has better effect on reducing the number of damage scoring compared to glibenclamide drug, so that the effect is close to the normal condition of the streptozotocin-non induced rat.

\section{Discussion}

Fat degeneration is characterized by abnormal fat accumulation in the liver parenchyma, may be spotted, zonal, or evenly distributed. Looks fat in liver cells due to normal process imbalances that affect fat levels inside and outside the liver tissue due to metabolic disorders (Vinary and Abdul 2005). The degeneration of fat is due to the substance of toxic substances, nutritional deficiencies, lipotropic substance deficiency such as choline and high-fat diet. toxins that cause degeneration of liver cells in the form of bacterial toxins, organic toxins (chloroform, carbon tetrachloride, glycosides, and alkalosides derived from certain plants) (Benirschke, 1982). Hydrophilic degeneration occurs due to cell membrane disruption so that fluid enters the cytoplasm, causing a small to large cytoplasmic cytoplasm. Cytoplasm is very swollen, pale, clear, contains a lot of water does not contain fat or glycogen (Kasno 2012).

The presence of infiltration of inflammatory cells, either in liver or kidney tissue is thought to be related to the body's response to some abnormalities due to the activation of the thermoregulator. The body suffering from inflammation will release various types of biochemical compounds, such as some types of glucocorticoid hormones and cytokines. The cytokine that is released plays an important role in the body's efforts to maintain inflammatory homeostasis. During inflammation the cytokine secretion increases, this will increase the inflammatory response. In addition, in the chronic inflammatory state, protective proteins resulting from inflammation (heat shock proteins, HSP) become uncontrolled, causing some types of cellular proteins to decline, apoptosis and tissue necrotic are also increasing (Huang et al. 2003).

Biochemical compounds in the peel extract of jengkol fruit (A. pauciflorum) such as tannins, flavonoids, alkaloids, quinones, steroids/triterpenoids, saponins, polyphenols can reduce cellular necrosis and increase regeneration of new tissues in cardiac myocardium. These compounds also act as antioxidants that help repair tissue damage to the heart. Jengkol fruit peel also contains protein, vitamin A, B vitamins, phosphorus, and calcium that plays a role in the development of the body and can repair back the damaged cells.

The phytochemical compounds in djenkol fruit are flavonoids, saponins (Elysa 2011) but not yet known how many levels of each substance contained in djenkol fruit, in this study there is non significant differences found between research groups suspected levels of flavonoids, saponins, and tannins in jengkol seeds insufficient amounts to decrease the amount of infiltration of inflammatory cells in rat's spleen.
Table 1. Average of necrosis cell and damage scoring after 14 days of treatment

\begin{tabular}{lcc}
\hline Treatment group & $\begin{array}{c}\text { Average of } \\
\text { necrosis cell }\end{array}$ & $\begin{array}{c}\text { Average of } \\
\text { damage scoring }\end{array}$ \\
\hline Negative control & $131.50 \pm 3.42^{\mathrm{a}}$ & $1.50 \pm 1.00^{\mathrm{a}}$ \\
Positive control (STZ) & $242.75 \pm 3.86^{\mathrm{b}}$ & $7.50 \pm 1.29^{\mathrm{b}}$ \\
$\mathrm{Pb}($ glibenclamide) & $182.00 \pm 2.94^{\mathrm{c}}$ & $4.00 \pm 0.00^{\mathrm{cd}}$ \\
$\mathrm{P} 1(385 \mathrm{mg} / \mathrm{kg} \mathrm{bw})$ & $160.25 \pm 2.75^{\mathrm{d}}$ & $3.00 \pm 0.82^{\mathrm{ad}}$ \\
$\mathrm{P} 2(770 \mathrm{mg} / \mathrm{kg} \mathrm{bw})$ & $153.50 \pm 9.40^{\mathrm{d}}$ & $2.50 \pm 1.73^{\mathrm{ad}}$ \\
$\mathrm{P} 3(1540 \mathrm{mg} / \mathrm{kg} \mathrm{bw})$ & $181.75 \pm 5.32^{\mathrm{c}}$ & $5.50 \pm 0.58^{\mathrm{bc}}$ \\
\hline
\end{tabular}

Note: Data were analyzed using ANOVA and Tukey test with 95\% confidence level. Different letters in one column show a real difference $(\mathrm{p}<0,05)$

Flavonoids are able to work as antioxidants in aloksaninduced pancreatic beta cells (Song et al. 2005). Flavonoids also act as antioxidants that can suppress the release of reactive $\mathrm{O}_{2}$ radicals thereby suppressing endothelial damage by inhibiting the initiation or propagation of oxidation chain reactions and as an anti-inflammatory that inhibits inflammatory reactions, thus preventing more macrophages (Lamson 2000).

Research on saponins shows that saponins can inhibit bile acid reabsorption (synthesized from cholesterol) by intestinal cells so that bile acids will soon be excreted with feces. To compensate for the loss of bile acids cholesterol in serum will be converted by the liver to bile acids so that there will be a decrease in blood cholesterol levels (Hedges 2007).

The results showed that the treatment using jengkol fruit peel extract (A. pauciflorum) can affect normal cell count, necrosis cell count, fat degeneration, hydropic degeneration, and inflammation of inflammatory cell, which is almost the same with negative control, without streptozotocin induction. Fruit ethanol extract of jengkol fruit having good effect on each parameter was at dose 385 and $770 \mathrm{mg} / \mathrm{kg}$ bw, which could decrease cell necrosis, and repair cell damage based on fat degeneration, hydropic degeneration, and inflammatory cell infiltration. This suggests that jengkol fruit peel extract (A. pauciflorum) has the potential to improve the histologic damage of rat $(R$. novergicus) heart that induced by streptozotocin.

Based on the results of this study, it can be concluded that the provision of jengkol fruit peel extract ( $A$. pauciflorum) can improve the damage of the histological structure of the spleen, which could be observed from the number of necrosis cells and score damage picture caused by fat degeneration, hydropic degeneration, and inflammatory cell inflammation on Wistar rat $(R$. norvegicus) induced by streptozotocin. The dose of ethanol extract from jengkol fruit peel (A. pauciflorum), which effectively repair the cell damage in female rat $(R$. norvegicus) wistar spleen induced by streptozotocin was $385 \mathrm{mg} / \mathrm{kg}$ bw. However, toxicity test of ethanol extract of jengkol fruit peel for 28 days is required to know the toxic level of jengkol fruit peel to other body organs, in order to prevent other negative effects that can be inflicted on people with diabetes mellitus. 


\section{REFERENCES}

Abeeleh MA. 2009. Induction of diabetes mellitus in rats using intraperitoneal streptozotocin: a comparison between 2 strains of rats. European J Sci Res 32 (3): 398-402.

Arnita. 2005. Wahana Komunikasi Lintas Spesialis. Majalah Farmacia 4 (2): 38-44. [Indonesian]

Benirschke KRM, Garner TC, Jones. 1982. Pathology of Laboratory Animals. Springer-Verlag, New York.

Cockram CS, Chan WB, Chan JCN, Chow CC, Yeung VTF, So WY, Li JKY, Ko GTC, Ma RCW. 2000. Glycaemic Control in Type 2 Diabetes: The Impact of Body Weight, $\beta$-cell Function and Patient Education. Quart J Med 93: 183-189.

Cooper DJ, Rosenfeld JV, Murray L, Arabi YM, Davies AR, D'Urso P, Kossmann T, Ponsford J, Seppelt I, Reilly P, Wolfe R. Decompressive Craniectomy in Diffuse Traumatic Brain Injury. $\mathrm{N}$ Engl J Med 364: 1493-1502.

Ebaid H, Jameel A, Ali M, Ahmed A, Kairy Z, Jamaan A, Ahmed R, Ibrahim MA, Khaled EI. 2015. Effect of STZ-Induced Diabetes on Spleen of Rats: Improvement by Camel Whey Proteins. Pakistan J. Zool 47 (4): 1109-1116.

Elysa. 2011. The Effect of Ethanol Extract of Djenkol Seed (Pithecellobium lobatum Benth.) to Decrease Blood Glucose Level of Male White Rats Wistar-Induced Allokan Strain. [Hon. Thesis]. North Sumatra University, Medan. [Indonesian]

Furman BL. 2015. Streptozotocin-induced diabetic models in mice and rats. Curr. Protoc. Pharmacol 70: 5471-5490.

Guyton AC, Hall J. 2010. Guyton and Hall Textbook of Medical Physiology 12th Edition. Elsevier, New York.

Hedges LJ, Lister CE. 2007. The Nutritional Attributes of Allium Species. Crop and Food Research Confidential Report No. 1814.

Huang KL, Wu CP, Chen YL, Kang BH, Lin YC. 2003. Heat stress attenuates air bubble-induced acute lung injury: a novel mechanism of diving acclimatization. J Appl Physiol 94: 1485-1490.

IACUC University of Connecticut. 2015. Standard Operating Procedure: Food Restriction in Rodents. http: //content.research.uconn.edu

Kasno PA. 2012. Hepatologic pathology and extra hepatic bile ducts. [Thesis]. Diponegoro University, Semarang. [Indonesian]

Khan J, Yadav Y, Srivastava Y, Pal PK. 2012. In vitro evaluation of antimicrobial properties of Carica papaya. Intl J Biol Pharm All Sci 1 (7): 933-945
Lamson, Davis, Matthew B. 2000. Antioxidants and cancer III: quercetin, alternative medicine. Rev J 5 (3): 196-208.

Li S, Pongmesa T, Huee-Li. 2009. A survey of knowledge on diabetes in the central region of Thailand. Intl Soc Pharmacoecon Outcomes Res 2: $110-113$.

Malini DM, Madihah, Kusmoro J, Kamilawati F, Iskandar J. 2017. Ethnobotanical study of medicinal plants in Karangwangi District of Cianjur, West Java. Biosaintifika 9 (2): 345-356. [Indonesian]

Mebius RE, Kraal G. 2005. Structure and function of the spleen. Nat Rev Immunol 5: 606-610.

Pramono E. 2002. The commercial use of traditional knowledge and medicinal plants in Indonesia. Multi-Stakeholder Dialoque on Trade Intellectual Property and Biological Resources in Asia. International Centre for Trade and Sustainable Development, Rajendrapur, India, 19-21 April 2002.

Ratimanjari DA. 2011. The effect of infusa herba sambiloto (Andrographis paniculata nees) on glibenclamide in lowering blood glucose level of male rats made by diabetes. [Essay]. University of Indonesia, Jakarta.

Sajedianfard J, Nazifi S, Shamsaei HA. 2014. The effects of oral administration of different doses of hydroalcoholic extract of silymarin on status of serum trace elements. Am J Anim Vet Sci 9 (3): 170-176.

Soegondo S, Soewondo P, Subekti I. 2011. Diagnosis dan klasifikasi diabetes melitus: penatalaksanaan diabetes melitus terpadu bagi dokter maupun edukator diabetes. Fakultas Kedokteran Universitas Indonesia, Jakarta. [Indonesian]

Song, Y, Joann EM, Julie EB, Howard DS, Simin L. 2005. Association of dietary flavonoids with risk of type 2 diabetes, and markers of insulin resistance and systemic inflammation in women: a prospective study and cross-sectional analysis. J Am College Nutr 24 (5): 376-384.

Syafnir L, Krishnamurti Y, Ilma M. 2014. Uji aktivitas antidiabetes ekstrak etanol kulit jengkol (Archidendron pauciflorum (Benth.) I.C. Nielsen). Prosiding SNaPP2014 Sains, Teknologi, dan Kesehatan 4 (1): 65-72. [Indonesian]

Szkudelski T. 2001. The mechanism of alloxan and streptozotocin action in $\beta$ cells of the rat pancreas. Physiol Res 50: 524-536.

Vinay K, Abdul K. 2005. Pathology. Elsevier Saunders, Philadelphia Pennsylvania.

Wild S, Roglic G, Green A. 2004. Global prevalence of diabetes. Diabetes Care 27: 1047-1053. 